\title{
Lead Organization
}

National Cancer Institute

\section{Source}

National Cancer Institute. Lead Organization. NCI Thesaurus. Code C63409.

The principal administrative organization responsible for the research conducted. 